\title{
Remote Collaboration in Higher Game Development Education. Online Practices and Learning Processes of Students between Professional Routines and Psychosocial Challenges
}

\author{
André Czauderna ${ }^{1}$ \& Emmanuel Guardiola ${ }^{1}$ \\ ${ }^{1}$ Cologne Game Lab, TH Köln, Cologne, Germany \\ Correspondence: André Czauderna, Cologne Game Lab, Technische Hochschule Köln, Schanzenstr. 28, 51063 \\ Köln, Germany. E-mail: andre.czauderna@th-koeln.de
}

Received: January 14, 2021

Accepted: February 8, $2021 \quad$ Online Published: February 20, 2021

doi:10.5539/hes.v11n2p1

URL: https://doi.org/10.5539/hes.v11n2p1

\begin{abstract}
The development of digital games over physical distance is a common practice in the gaming industry, yet widely neglected in the curricula of digital game development programs at university level. The coronavirus pandemic, however, pushed project-oriented game programs all over the world towards an implementation of ad hoc approaches to remote development in their project-based courses. The present article demonstrates practice-based research examining such a course and its 30 third-year undergraduate students of game arts, game design, and game programming, who remotely collaborated in interdisciplinary groups of two to five persons over the course of half a semester during Germany's logdown in spring 2020. Applying a mixed-method approach including quantitative and qualitative analyses of survey data $(n=22)$ and qualitative content analyses of students' postmortem documentations $(n=30)$, this exploratory study reconstructed the online practices, experiences, and learning processes of these students between their professional routines and psychosocial challenges. The results of this study can be used in curriculum development to inform the advancement of courses focused on the development of prototypes over physical distance, which may not only be relevant for the field of games education, but also for related creative and project-oriented fields of higher education, such as design, digital media, and software engineering.
\end{abstract}

Keywords: community of practice, coronavirus pandemic, covid-19, distance education, game development, higher education, online collaboration, remote learning, remote work.

\section{Introduction}

The development of digital products over physical distance is a common practice in the gaming industry as well as other creative industries and software engineering. It includes both the development over multiple sites in different countries and remote work (respectively telework) of individuals. A single game title by studios such as Ubisoft may feature the work of hundreds of collaborators from a variety of disciplinary and cultural backgrounds, split between multiple studios and supporting structures (e.g. concerned with testing, localization, and marketing) in different countries and time zones. Furthermore, additional employees and freelancers contribute remotely from their home offices. As a result of the coronavirus pandemic, remote work saw an immense increase during 2020 (Francis, 2020).

In contrast, so far, at least prior to the coronavirus pandemic, most higher education game development programs have neglected the development of games over physical distance. This is insofar problematic as remote collaboration requires particular knowledge and skills when it comes to workflows, project and knowledge management, communication, psychology, etc. (e.g. Damian \& Zowghi, 2003). In particular, the psychosocial challenges of working remotely and/or over countries including time differences and cultural diversities should not be underestimated (e.g. Olson \& Olson, 2000).

In spring 2020, the coronavirus pandemic forced higher education to switch from traditional on-site instruction to synchronous and asynchronous forms of distance education at a moment's notice (Bozkurt et al., 2020; Kerres, 2020). Thereby, many universities could not rely on pre-planned distance education, but needed to improvise and implement "an emergency remote education" (Bozkurt et al., 2020). For game development education in its project-oriented form (Czauderna, 2018), it was not only about substituting lectures and seminars by their online 
adaptations, but also about enabling students to collaborate in interdisciplinary teams on game prototypes without having any physical meeting point on campus.

At the Cologne Game Lab (CGL) of TH Köln, these challenges were interpreted as a chance to iterate on approaches to instruct students in the development of digital games over physical distance. In the summer term 2020, in the BA program "Digital Games", all project-based courses required students to develop their games remotely. This paper reports on practice-based exploratory research examining one of these project-based courses and its 30 third-year undergraduate students of game arts, game design, and game programming (see section 2.1 for a detailed description of this course).

Applying a mixed-method approach - namely, quantitative and qualitative analysis of survey data and qualitative content analysis of students' postmortem documentations - the paper discusses the following research questions:

- How do students communicate and collaborate in a team-based development project over physical distance using a variety of digital tools?

- How do students judge their experiences when it comes to challenges and enjoyment - considering both professional practice and psychosocial well-being?

- How do students perceive their learning processes and outcomes? How do they learn together and support each other as members of a community of practice?

Our study looks at collaborative practices and learning processes from the perspective of social theories of learning, as suggested e.g. by Jean Lave and Étienne Wenger in their theory of situated learning (Lave \& Wenger, 1991). In this sense, learning is observed less as an individual, psychological phenomenon, but in particular as a social, collective process. It is assessed not only as a change of individual cognition, but also as "changing participation in changing practices" (Lave, 1996, p. 150). Consequently, our object of study is not only the individual learning in isolation, but the learning individual as part of a community of practice (Wenger, 2008), and thus the social interaction of a community of practice. More precisely, in the case of the present study, we examine collaborative practices and learning processes inside a small team of two to five students - as members of a community of practice, connected by technological tools - developing digital games together.

The results of our practice-based exploratory research should allow curriculum developers and faculty members to derive conclusions for future educational practices in game development education and related fields of higher education.

\section{Method}

This chapter outlines the examined remote development project as well as it describes our methods of data collection and analysis.

\subsection{Outline of the Remote Development Project}

We conducted our practice-based exploratory research in a project-centered course in the sixth semester of our BA program "Digital Games". In the examined course - which was led by one of the authors (E.G.), while the other author (A.C.) acted as one of several additional mentors and examiners from different disciplines third-year students received the task of collaboratively developing so-called impact games, i.e., games with a purpose beyond entertainment trying to make a real-world impact. The objective of an impact game is to have a measurable effect on people, society, or organizations. This impact could be of different kinds including knowledge, awareness of a cause, behavioral changes, cognitive or physical changes for health purpose, promotion of a culture or an idea, etc. In the observed course, the impact games were supposed to have a topical relation to "the corona situation". Over the period of seven weeks and three days, students worked in eleven groups with two to five students each. During the time of the project, students were not required to take other courses. They thus had a lot of time to concentrate on the project.

After one week, each group had to submit a five-minute video to the online platform Spaces (which is a merger between a social network and an e-learning platform developed by the Köln International School of Design) in order to explain their project (first pitch). Three weeks later, students were required to exhibit a ten-minute video on the same platform to show their progress (intermediate presentation). Both presentations - in asynchronous mode - offered students the opportunity to receive written feedback from peers and faculty. For students, it was mandatory to comment in written form on at least two other projects subsequent to the above-mentioned presentations. At the end of the project, students needed to present their final results in a Zoom meeting (in a ten-minute final presentation) as well as to deliver a digital game and a protocol of how to measure the impact of their game. One week after the end of the actual project work, each student was obliged to submit a postmortem 
documentation on their individual work.

In their previous semesters, students had developed a variety of games in interdisciplinary teams, but never in a setting exclusively grounded on remote development. The majority of this collaborative project, which ran from April 1 to May 22, 2020, took place during the first coronavirus lockdown in Germany. Therefore, all facilities of the Cologne Game Lab were closed, and students and faculty members alike were forced to physically stay away from each other (unless in the rare case of students living together). It can be assumed that under these circumstances many students were exposed to additional psychosocial stress. Discussions revealed that many lost their jobs early in the pandemic, suffered from social isolation, and/or worried about their own health and the health of relatives and friends. In addition, it must be taken into account that online learning and remote work as such can be linked to stress and communication issues (e.g. Mheidly et al., 2020).

\subsection{Data Collection and Analysis}

In order to answer our research questions, we applied a mixed-method approach. First, we collected data through a survey we mailed out to all students after the end of the project $(n=22)$. In addition to standardized questions, this survey included a couple of open questions. Second, we collected postmortem documentations (of 1500 to 2000 words) from all students who worked in eleven groups of two to five students - including one student who collaborated with external contributors $(\mathrm{n}=30)$. A postmortem is a well-established tool in the gaming industry and game development education which consists of a reflection of successful and unsuccessful aspects of a project and concludes with lessons learned. For this project, students were asked to include a section on their experiences with remote work during the project.

The sample of this study consists of students from our own project-centered course in the sixth semester of the BA program "Digital Games" (as described in section 2.1). Due to our practice-based research design, it would not have been feasible to include students from other institutions. Our sample thus cannot be representative of all game development students and programs. The postmortem sample $(n=30)$ is bigger than the survey sample $(n=22)$, because the submission of a postmortem was a requirement to pass the course, whereas the completion of the survey was optional. In the survey, we collected demographic data, such as age and gender. Our survey respondents were between 20 and 39 years old. The average age was 25.8 years. $27.3 \%$ of respondents were female and $63.6 \%$ male, while $9.1 \%$ preferred not to say. We did not collect students' nationality, but it should be noted that the group consisted of students from a variety of nationalities and cultural backgrounds.

Answers to open survey questions as well as postmortems were analyzed using qualitative content analysis (Mayring, 2004) with the help of MAXQDA, a software package for qualitative data analysis. The code system consists of the following categories: "description of remote work", "judgement of remote work", and "perception of learning processes and outcomes". The results, presented in the next chapter, are based on a triangulation of the quantitative analysis of survey data as well as the qualitative content analysis of answers to open questions and postmortems.

\section{Results}

This chapter illustrates the results of our study in three sections: (1) Communication and Collaboration, (2) Challenges and Enjoyment, (3) Learning Processes and Outcomes.

\subsection{Communication and Collaboration}

This section outlines how students communicated and collaborated during their projects in teams of two to five members.

\subsubsection{Context}

Most of our students (71.43\%) perceived their routines and environments as significantly different than before the coronavirus pandemic (see Figure 1). Therefore, the results of our study must be seen in light of the particular conditions during Germany's coronavirus logdown in spring 2020. 


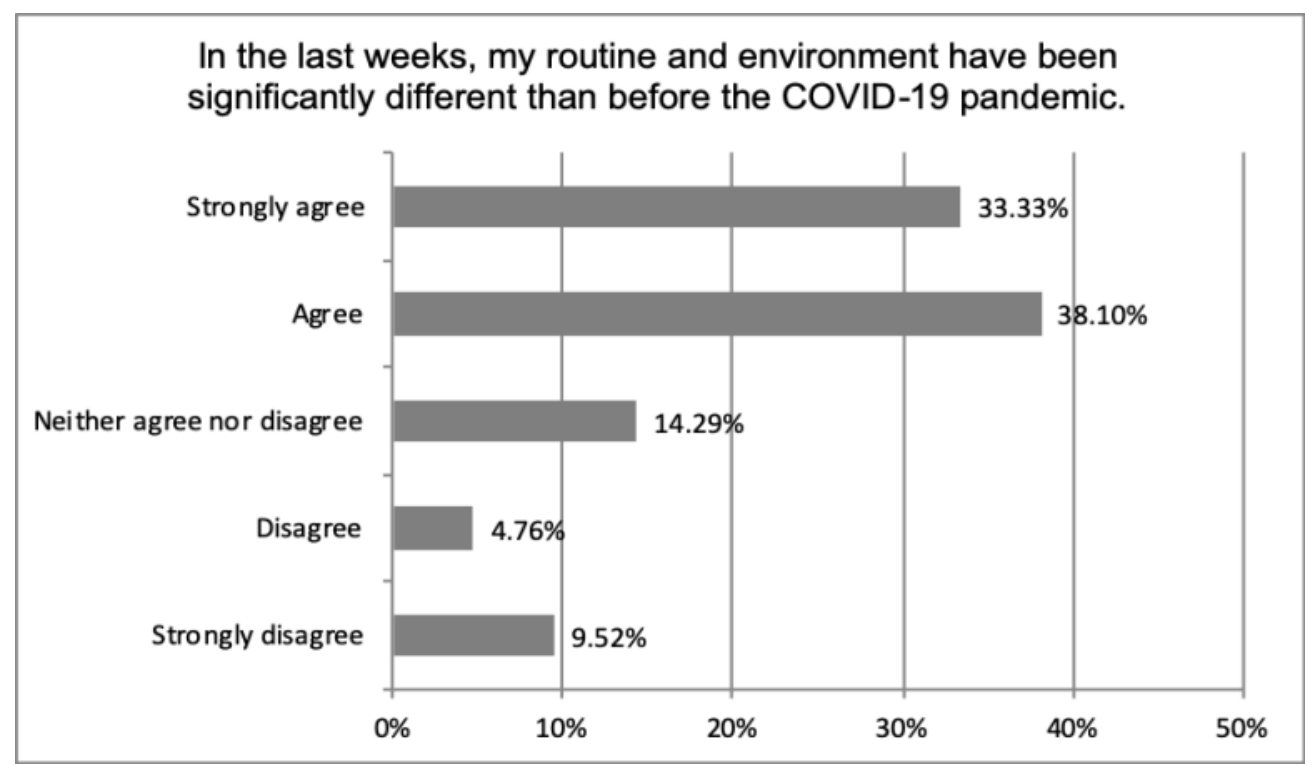

Figure 1. Self-perceived change of routines and environments during the coronavirus pandemic (answered by 21, skipped by 1)

As sixth-semester students, they bring at least two and a half years' experience in game development. All of them have at least some experience with remote development; more than a quarter of them own a lot $(23.81 \%)$ or even a great deal $(4.76 \%)$ of experience (see Figure 2$)$.

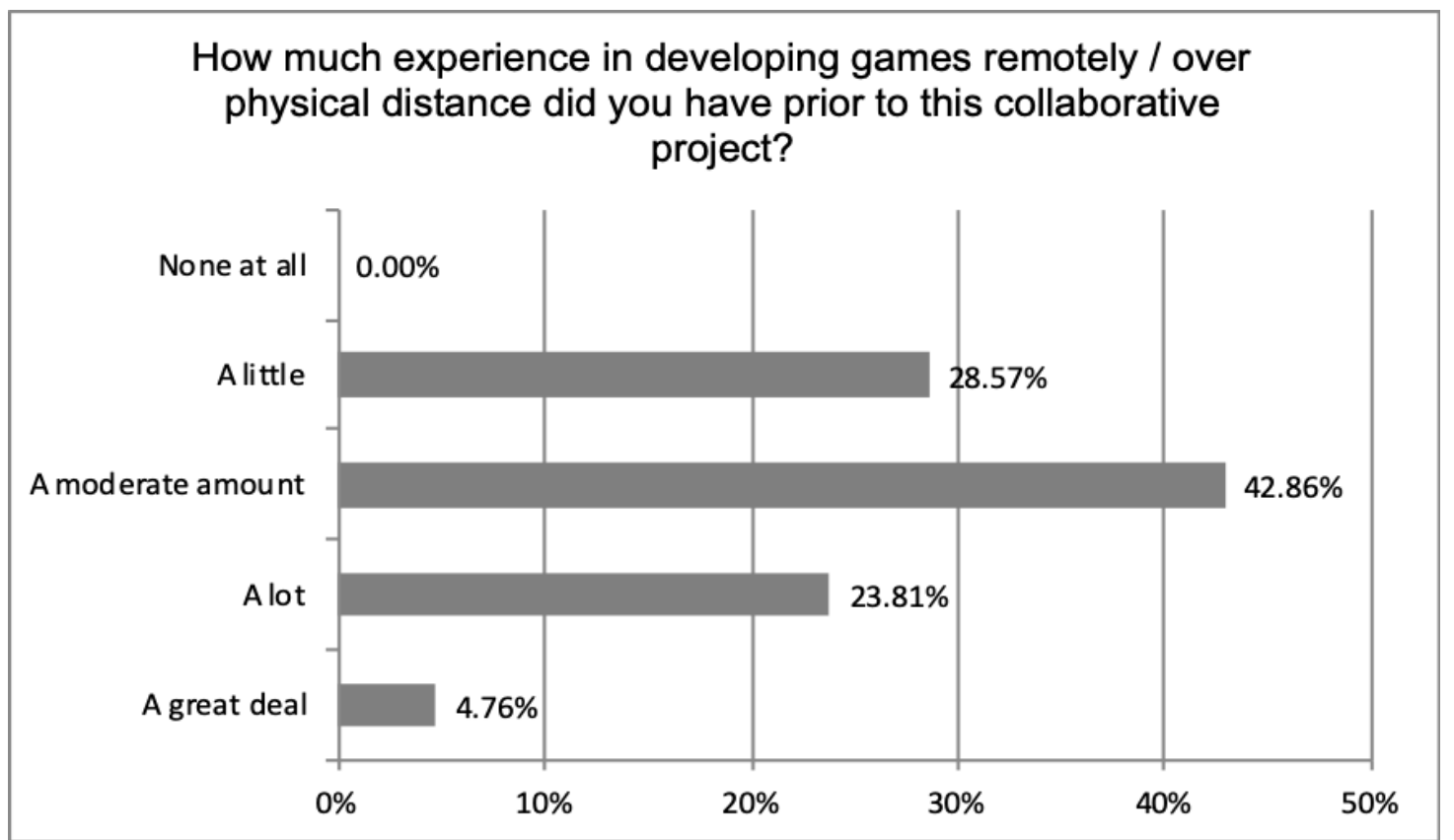

Figure 2. Prior experience in developing games remotely / over physical distance (answered by 21, skipped by 1)

\subsubsection{Usage of Tools}

During the observed collaborative project, students were free to choose their own digital tools. As shown in Table 1, two tools stood out: The majority of students used Discord (90.5\%) and Google Drive (61.9\%) several times a week. In contrast, email, for instance, has not been a common means of project-related communication or collaboration. 
Table 1. How often did you use the following tools in the impact games development project inside of your own team? (answered by 21, skipped by 1 )

\begin{tabular}{|c|c|c|c|c|c|c|c|}
\hline & NEVER & $\begin{array}{l}\text { ONCE A MONTH } \\
\text { OR LESS }\end{array}$ & $\begin{array}{l}\text { FEW TIMES A } \\
\text { MONTH }\end{array}$ & $\begin{array}{l}\text { ONCE OR TWICE } \\
\text { A WEEK }\end{array}$ & $\begin{array}{l}\text { SEVERAL TIMES } \\
\text { A WEEK }\end{array}$ & TOTAL & $\begin{array}{l}\text { WEIGHTED } \\
\text { AVERAGE }\end{array}$ \\
\hline Email & $\begin{array}{r}70.0 \% \\
14\end{array}$ & $\begin{array}{r}10.0 \% \\
2\end{array}$ & $\begin{array}{r}5.0 \% \\
1\end{array}$ & $\begin{array}{r}15.0 \% \\
3\end{array}$ & $\begin{array}{r}0.0 \% \\
0\end{array}$ & 20 & 1.65 \\
\hline WhatsApp & $\begin{array}{r}55.0 \% \\
11\end{array}$ & $\begin{array}{r}5.0 \% \\
1\end{array}$ & $\begin{array}{r}10.0 \% \\
2\end{array}$ & $\begin{array}{r}15.0 \% \\
3\end{array}$ & $\begin{array}{r}15.0 \% \\
3\end{array}$ & 20 & 2.30 \\
\hline Discord & $\begin{array}{r}0.0 \% \\
0\end{array}$ & $\begin{array}{r}0.0 \% \\
0\end{array}$ & $\begin{array}{r}9.5 \% \\
2\end{array}$ & $\begin{array}{r}0.0 \% \\
0\end{array}$ & $\begin{array}{r}90.5 \% \\
19\end{array}$ & 21 & 4.81 \\
\hline Zoom & $\begin{array}{r}85.0 \% \\
17\end{array}$ & $\begin{array}{r}10.0 \% \\
2\end{array}$ & $\begin{array}{r}5.0 \% \\
1\end{array}$ & $\begin{array}{r}0.0 \% \\
0\end{array}$ & $\begin{array}{r}0.0 \% \\
0\end{array}$ & 20 & 1.20 \\
\hline Skype & $\begin{array}{r}89.5 \% \\
17\end{array}$ & $\begin{array}{r}0.0 \% \\
0\end{array}$ & $\begin{array}{r}5.3 \% \\
1\end{array}$ & $\begin{array}{r}5.3 \% \\
1\end{array}$ & $\begin{array}{r}0.0 \% \\
0\end{array}$ & 19 & 1.26 \\
\hline $\begin{array}{l}\text { Microsoft } \\
\text { Teams }\end{array}$ & $\begin{array}{r}100.0 \% \\
20\end{array}$ & $\begin{array}{r}0.0 \% \\
0\end{array}$ & $\begin{array}{r}0.0 \% \\
0\end{array}$ & $\begin{array}{r}0.0 \% \\
0\end{array}$ & $\begin{array}{r}0.0 \% \\
0\end{array}$ & 20 & 1.00 \\
\hline Trello & $\begin{array}{r}70.0 \% \\
14\end{array}$ & $\begin{array}{r}5.0 \% \\
1\end{array}$ & $\begin{array}{r}0.0 \% \\
0\end{array}$ & $\begin{array}{r}20.0 \% \\
4\end{array}$ & $\begin{array}{r}5.0 \% \\
1\end{array}$ & 20 & 1.85 \\
\hline Slack & $\begin{array}{r}100.0 \% \\
20\end{array}$ & $\begin{array}{r}0.0 \% \\
0\end{array}$ & $\begin{array}{r}0.0 \% \\
0\end{array}$ & $\begin{array}{r}0.0 \% \\
0\end{array}$ & $\begin{array}{r}0.0 \% \\
0\end{array}$ & 20 & 1.00 \\
\hline $\begin{array}{l}\text { Google } \\
\text { Drive }\end{array}$ & $\begin{array}{r}0.0 \% \\
0\end{array}$ & $\begin{array}{r}0.0 \% \\
0\end{array}$ & $\begin{array}{r}14.3 \% \\
3\end{array}$ & $\begin{array}{r}23.8 \% \\
5\end{array}$ & $\begin{array}{r}61.9 \% \\
13\end{array}$ & 21 & 4.48 \\
\hline Dropbox & $\begin{array}{r}85.0 \% \\
17\end{array}$ & $\begin{array}{r}10.0 \% \\
2\end{array}$ & $\begin{array}{r}5.0 \% \\
1\end{array}$ & $\begin{array}{r}0.0 \% \\
0\end{array}$ & $\begin{array}{r}0.0 \% \\
0\end{array}$ & 20 & 1.20 \\
\hline Sciebo & $\begin{array}{r}95.0 \% \\
19\end{array}$ & $\begin{array}{r}5.0 \% \\
1\end{array}$ & $\begin{array}{r}0.0 \% \\
0\end{array}$ & $\begin{array}{r}0.0 \% \\
0\end{array}$ & $\begin{array}{r}0.0 \% \\
0\end{array}$ & 20 & 1.05 \\
\hline $\begin{array}{l}\text { Unity } \\
\text { Teams }\end{array}$ & $\begin{array}{r}70.0 \% \\
14\end{array}$ & $\begin{array}{r}0.0 \% \\
0\end{array}$ & $\begin{array}{r}0.0 \% \\
0\end{array}$ & $\begin{array}{r}5.0 \% \\
1\end{array}$ & $\begin{array}{r}25.0 \% \\
5\end{array}$ & 20 & 2.15 \\
\hline Outlook & $\begin{array}{r}95.0 \% \\
19\end{array}$ & $\begin{array}{r}5.0 \% \\
1\end{array}$ & $\begin{array}{r}0.0 \% \\
0\end{array}$ & $\begin{array}{r}0.0 \% \\
0\end{array}$ & $\begin{array}{r}0.0 \% \\
0\end{array}$ & 20 & 1.05 \\
\hline $\begin{array}{l}\text { Google } \\
\text { Calendar }\end{array}$ & $\begin{array}{r}65.0 \% \\
13\end{array}$ & $\begin{array}{r}5.0 \% \\
1\end{array}$ & $\begin{array}{r}0.0 \% \\
0\end{array}$ & $\begin{array}{r}5.0 \% \\
1\end{array}$ & $\begin{array}{r}25.0 \% \\
5\end{array}$ & 20 & 2.20 \\
\hline Spaces & $\begin{array}{r}55.0 \% \\
11\end{array}$ & $\begin{array}{r}15.0 \% \\
3\end{array}$ & $\begin{array}{r}25.0 \% \\
5\end{array}$ & $\begin{array}{r}5.0 \% \\
1\end{array}$ & $\begin{array}{r}0.0 \% \\
0\end{array}$ & 20 & 1.80 \\
\hline
\end{tabular}

Discord is an instant messaging and digital distribution platform. It allows users to create communities called servers and to communicate via voice calls, video calls, and text messaging. The particular popularity of this platform may be explained by its prevalence in the gaming community as well as a perceived functional superiority over other tools, as the following statement by a student points out (Endnote 1):

We decided to use Discord as our main means of communication, as we all already had accounts and are well aware of how it works. Also, it offers better voice quality than most other platforms while adding the option to have multiple text channels to organize the project. (G6/S1)

A lot of the above-mentioned tools have been used by many of our students prior to the observed collaborative project in a game development context. Discord, for instance, has been previously applied by all of our respondents (see Figure 3). 


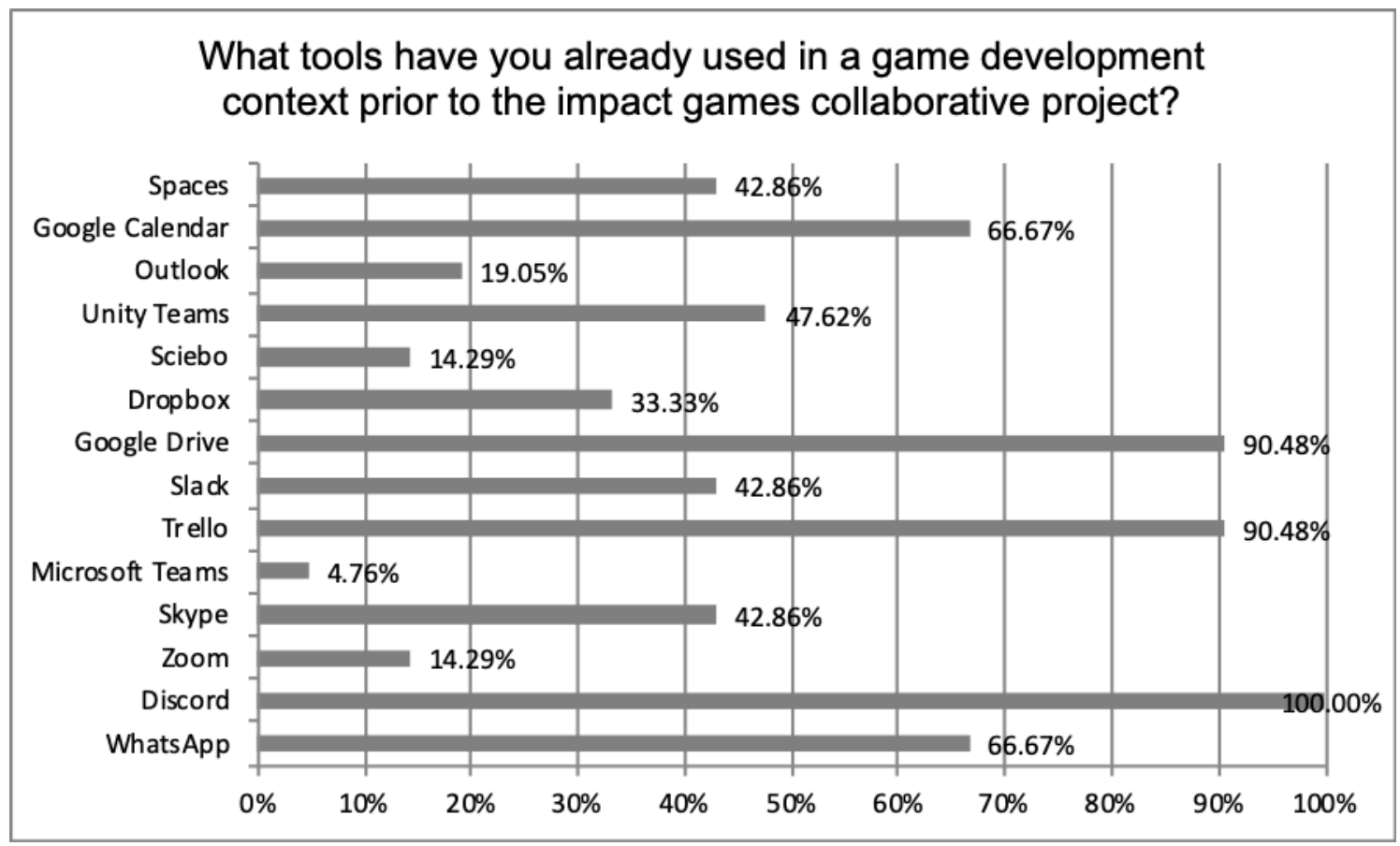

Figure 3. Tools used prior to the remote development project (answered by 21, skipped by 1)

\subsubsection{Written vs. Oral Communication}

Asked to compare written and oral forms of communication respectively the underlying tools in the digital sphere, most students (65\%) assessed text-based channels on the one hand and audio- and/or video-based channels on the other hand as equally important for the success of their project, while nobody assumed that text-based channels alone were more important for their successful professional communication (see Figure 4).

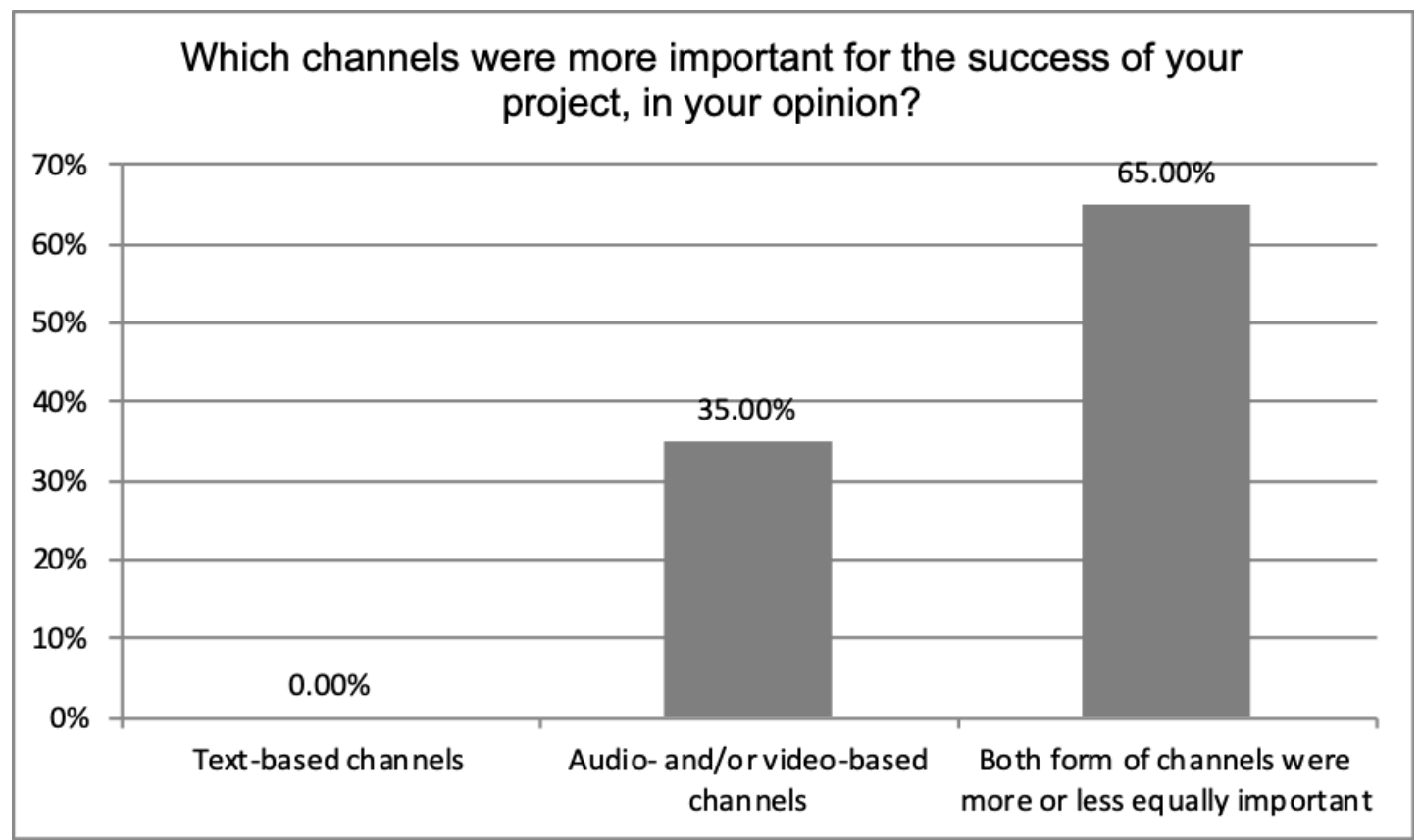

Figure 4. Importance of channel types (answered by 20, skipped by 2)

In the following statement, a student illustrated the perceived superiority of oral communication over written communication for their particular purpose: 
Whenever we had a presentation to prepare, we would have discord calls during which we prepared the entire presentation together, making sure all aspects of our process were captured accurately in them. This went surprisingly well and I realized that it's a lot more productive to do these things via calls than in written form over emails/chats. (G10/S1)

\subsubsection{Audio and Video Conferences}

While the majority of our students (61.91\%) met in video conferences "once or twice a week" or even "several times a week", a third of our students (33.33\%) never organized a video conference during the project - though they may be involved in audio conferences (see Figure 5):

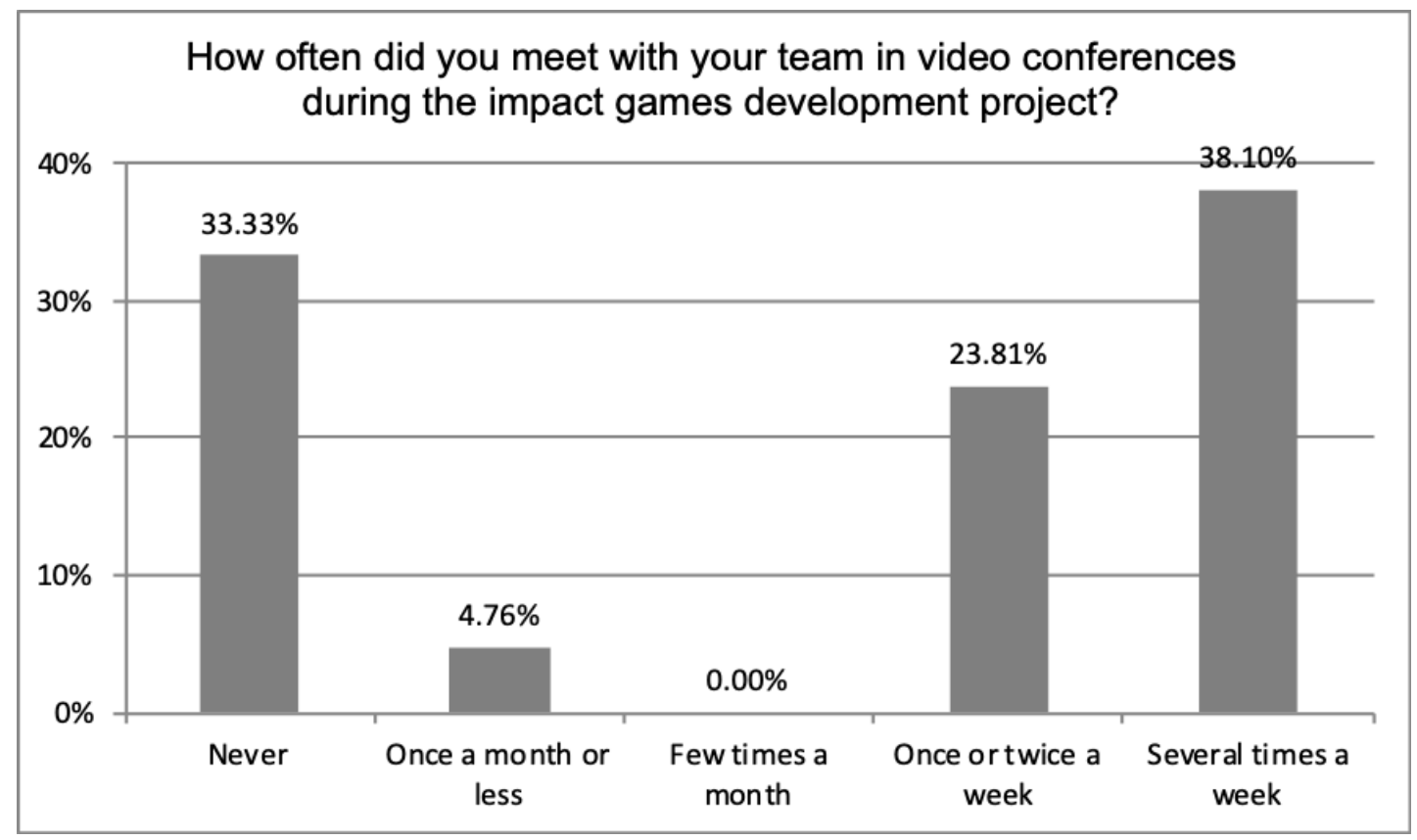

Figure 5. Frequency of video conferences (answered by 21, skipped by 1)

According to our survey data, the video conferences covered a variety of topics that came up "in many" or even "in every or almost every conference". The "distribution and sharing of work" was the most frequently covered topic, at least it has the highest number of respondents (69.2\%) who said that this topic was covered "in every or almost every conference" (see Table 2):

Table 2. How often did you cover the following topics during videoconferences? (answered by 13, skipped by 9)

\begin{tabular}{|c|c|c|c|c|c|c|}
\hline & NEVER & $\begin{array}{l}\text { IN SOME } \\
\text { CONFERENCES }\end{array}$ & $\begin{array}{l}\text { IN MANY } \\
\text { CONFERENCES }\end{array}$ & $\begin{array}{l}\text { IN EVERY OR ALMOST } \\
\text { EVERY CONFERENCE }\end{array}$ & TOTAL & $\begin{array}{l}\text { WEIGHTED } \\
\text { AVERAGE }\end{array}$ \\
\hline $\begin{array}{l}\text { General creative direction of } \\
\text { the project }\end{array}$ & $\begin{array}{r}0.0 \% \\
0\end{array}$ & $\begin{array}{r}15.4 \% \\
2\end{array}$ & $\begin{array}{r}53.8 \% \\
7\end{array}$ & $\begin{array}{r}30.8 \% \\
4\end{array}$ & 13 & 3.15 \\
\hline $\begin{array}{l}\text { Distribution / sharing of } \\
\text { work }\end{array}$ & $\begin{array}{r}0.0 \% \\
0\end{array}$ & $\begin{array}{r}15.4 \% \\
2\end{array}$ & $\begin{array}{r}15.4 \% \\
2\end{array}$ & $\begin{array}{r}69.2 \% \\
9\end{array}$ & 13 & 3.54 \\
\hline $\begin{array}{l}\text { Progression of project / } \\
\text { milestones }\end{array}$ & $\begin{array}{r}7.7 \% \\
1\end{array}$ & $\begin{array}{r}7.7 \% \\
1\end{array}$ & $\begin{array}{r}46.2 \% \\
6\end{array}$ & $\begin{array}{r}38.5 \% \\
5\end{array}$ & 13 & 3.15 \\
\hline Specialist issues & $\begin{array}{r}0.0 \% \\
0\end{array}$ & $\begin{array}{r}30.8 \% \\
4\end{array}$ & $\begin{array}{r}23.1 \% \\
3\end{array}$ & $\begin{array}{r}46.2 \% \\
6\end{array}$ & 13 & 3.15 \\
\hline $\begin{array}{l}\text { Feedback to team } \\
\text { members' work }\end{array}$ & $\begin{array}{r}7.7 \% \\
1\end{array}$ & $\begin{array}{r}30.8 \% \\
4\end{array}$ & $\begin{array}{r}15.4 \% \\
2\end{array}$ & $\begin{array}{r}46.2 \% \\
6\end{array}$ & 13 & 3.00 \\
\hline $\begin{array}{l}\text { Preparation of pitches and } \\
\text { presentations in class }\end{array}$ & $\begin{array}{r}0.0 \% \\
0\end{array}$ & $\begin{array}{r}46.2 \% \\
6\end{array}$ & $\begin{array}{r}46.2 \% \\
6\end{array}$ & $\begin{array}{r}7.7 \% \\
1\end{array}$ & 13 & 2.62 \\
\hline $\begin{array}{l}\text { Well-being of team } \\
\text { members }\end{array}$ & $\begin{array}{r}8.3 \% \\
1\end{array}$ & $\begin{array}{r}33.3 \% \\
4\end{array}$ & $\begin{array}{r}25.0 \% \\
3\end{array}$ & $\begin{array}{r}33.3 \% \\
4\end{array}$ & 12 & 2.83 \\
\hline $\begin{array}{l}\text { (Other) non-work related } \\
\text { matters }\end{array}$ & $\begin{array}{r}16.7 \% \\
2\end{array}$ & $\begin{array}{r}25.0 \% \\
3\end{array}$ & $\begin{array}{r}8.3 \% \\
1\end{array}$ & $\begin{array}{r}50.0 \% \\
6\end{array}$ & 12 & 2.92 \\
\hline
\end{tabular}


The following statements offer insights into how students' communication and collaboration in audio and video conferences were structured:

We voice chatted at varying intervals during the project. When everyone knew what to do, we could go a week without voice chatting and just writing on discord every day. But when closer to the presentations, we talked every day or every other day. During our calls, we would talk about what needed to be done the soonest, assign tasks, brainstorm ideas and prepare our presentations. (G6/S2)

As our main communication tool, we used Discord. Twice the week we would have a meeting. Our usual agenda was:

1. What did we work on

2. Discussing the work and how to develop it further, if needed

3. What are our next tasks

4. Giving out 'homework' for everyone

5. Setting a new date for our meeting

While these meetings were always really really long in the past while meeting face to face, ours were really short and quick to the point. Usually it would take around an hour, 2 hours Maximum. (G5/S1)

In some cases, the conferences spilled to the rest of the work day; some students kept in touch all over the day:

We met quite frequently to discuss the state of the project on Discord on then started working on our individual tasks that were derived from our desired outcome of the current segment of the project we were in. While not everything required us to collaborate all of the time, most of the time we stayed in voice chat to exchange ourselves not only about the project but also about things happening around us. This set a really nice working atmosphere and helped me quite a bit with focusing on working on the project instead of doing everything else. (G9/S1)

With us both being programmers, [my colleague] and I ended up working together over Discord a lot, with us working on the project while at the same time being on a call with Discords screen share function running so we could easily help each other with any problems that might occur. Especially during the last two weeks of development, we spent a lot of time fine-tweaking systems together, which ended up being extremely productive. (G6/S3)

Another thing that we found out while working remotely is that it's 10 times more productive to work together in a call, than to just give out a task and wait until we meet again to check on everybody's progress. Writing on Discord was useful, but working while on call surely beats everything else. $(\mathrm{G} 2 / \mathrm{S} 2)$

In general, the communication during audio and video conferences was embedded in a complex network of digital tools and developer practices, as the following statement reveals:

Firstly, we had set up a Discord server with different channels to keep everything sorted out. Secondly, we created a Google Drive folder dedicated to this project along with permission for everyone in the team. Drive folder is also sorted out based on different aspects and specializations for the game. Besides, we have found that 'G Suit by Google' provides tools such as Jamboard, Sheets, Docs, Slides etc. These tools helped us tremendously to work together in a digital space. Additionally, the whole team decided to adapt the Scrum method for project management using 'Trello' to keep count on tasks and their progress. The team decided to communicate minimum two times in a week to inform the team about the progress and directions. In some weeks it has been seen that we have contacted each other several times in a week and use screen sharing to show progress or ideas or solve problems together. Being in an online space, it was not easier. However, we have managed to do it regularly. [...] In the ideation phase, we have created a Google Jamboard to work together and throw up our ideas. (G4/SUK)

\subsubsection{Recreational Communication and Activities}

Some of our students assume that social interactions beyond game development inside the development team is good for team members' well-being as well as it improves work dynamics. The following statement offers an example of such an opinion:

Addressing the elephant in the room: This project came with the unique challenge of not being able to meet up in person whatsoever because of the COVID-19 pandemic. While I certainly didn't miss travelling to Cologne for 2 hours back and forth respectively, I do feel like a certain aspect of 
community is lost when working exclusively from home. However, I feel like our team handled the restrictions really well. We ended up scheduling Discord-meetings very regularly to not only discuss gameplay, art and programming-related issues and plan our roadmap going forward, but also to chat with each other and socialize. I genuinely believe that this aspect of us coming together helped keep us all sane during development and helped raise morale in these crazy times. (G6/S3)

Around half of our respondents (47.3\%) said in our survey that they had online conversations and/or activities with team members during the impact games project that resembled and/or substituted similar on-site conversations and/or activities. In an open question of our survey, some students described these recreational activities. In addition to chatting, playing games online was a popular shared activity among game development students, as described in the following sample statements:

We often stayed in the chat after our usual meetings (every 2-3 days) and shared news and chatted about private stuff going on. (SUK)

We played online some games together and talked over voice chat about the game or personal stuff. We also sometimes just stayed inside the vc after our meetings to talk to each other, while working. (SUK)

Regular chatting about how things are going with our families/friends etc. (We're also close friends outside of the project), how everybody is handling the situation and random discussions about literally anything - We sometimes met up with other friends after work (over discord) and played games like Boardgame Simulator, Jackbox or Minecraft. (SUK)

\subsection{Challenges and Enjoyment}

This section reports on students' judgements of their experiences when it comes to challenges and enjoyment, i.e., their perceived challenges and enjoyment.

\subsubsection{Perceived Challenges}

Table 3 offers evidence on the occurrence of problems related to the conditions of remote work and social distancing. Overall, more students perceived problems when it comes to social and psychological aspects (including their well-being) than in the areas of technology, management, communication, and collaboration. 75\% of students "agree" or "strongly agree" that they "had more difficulties than usual to separate private and university activities". $85 \%$ said (i.e., "agree" or "strongly agree") that they "missed being together with their team members in "real life"". In this context, it does not come as a surprise that $60 \%$ had more difficulties than usual to motivate themselves and $55 \%$ found it harder to concentrate on the project. 
Table 3. Problems that occurred during development due to the fact that students worked remotely / under the conditions of social distancing - in comparison to previous collaborative projects (answered by 20, skipped by 2)

\begin{tabular}{|c|c|c|c|c|c|c|c|}
\hline & $\begin{array}{l}\text { STRONGLY } \\
\text { DISAGREE }\end{array}$ & DISAGREE & $\begin{array}{l}\text { NEITHER } \\
\text { AGREE } \\
\text { NOR } \\
\text { DISAGREE }\end{array}$ & AGREE & $\begin{array}{l}\text { STRONGLY } \\
\text { AGREE }\end{array}$ & TOTAL & $\begin{array}{l}\text { WEIGHTED } \\
\text { AVERAGE }\end{array}$ \\
\hline $\begin{array}{l}\text { My team struggled more than usual } \\
\text { with technical problems (with } \\
\text { software, hardware, internet } \\
\text { connection, etc.). }\end{array}$ & $\begin{array}{r}25.0 \% \\
5\end{array}$ & $\begin{array}{r}25.0 \% \\
5\end{array}$ & $\begin{array}{r}15.0 \% \\
3\end{array}$ & $\begin{array}{r}35.0 \% \\
7\end{array}$ & $\begin{array}{r}0.0 \% \\
0\end{array}$ & 20 & 2.60 \\
\hline $\begin{array}{l}\text { Physical distance between team } \\
\text { members made it more difficult to } \\
\text { manage the project. }\end{array}$ & $\begin{array}{r}15.0 \% \\
3\end{array}$ & $\begin{array}{r}45.0 \% \\
9\end{array}$ & $\begin{array}{r}15.0 \% \\
3\end{array}$ & $\begin{array}{r}10.0 \% \\
2\end{array}$ & $\begin{array}{r}15.0 \% \\
3\end{array}$ & 20 & 2.65 \\
\hline $\begin{array}{l}\text { Physical distance between team } \\
\text { members made the exchange of } \\
\text { feedback to each others' work } \\
\text { more difficult. }\end{array}$ & $\begin{array}{r}15.0 \% \\
3\end{array}$ & $\begin{array}{r}30.0 \% \\
6\end{array}$ & $\begin{array}{r}15.0 \% \\
3\end{array}$ & $\begin{array}{r}25.0 \% \\
5\end{array}$ & $\begin{array}{r}15.0 \% \\
3\end{array}$ & 20 & 2.95 \\
\hline $\begin{array}{l}\text { Physical distance between team } \\
\text { members made collaboration more } \\
\text { difficult. }\end{array}$ & $\begin{array}{r}15.0 \% \\
3\end{array}$ & $\begin{array}{r}20.0 \% \\
4\end{array}$ & $\begin{array}{r}15.0 \% \\
3\end{array}$ & $\begin{array}{r}30.0 \% \\
6\end{array}$ & $\begin{array}{r}20.0 \% \\
4\end{array}$ & 20 & 3.20 \\
\hline $\begin{array}{l}\text { Physical distance between team } \\
\text { members made it more difficult to } \\
\text { follow a common creative direction. }\end{array}$ & $\begin{array}{r}10.5 \% \\
2\end{array}$ & $\begin{array}{r}26.3 \% \\
5\end{array}$ & $\begin{array}{r}15.8 \% \\
3\end{array}$ & $\begin{array}{r}21.1 \% \\
4\end{array}$ & $\begin{array}{r}26.3 \% \\
5\end{array}$ & 19 & 3.26 \\
\hline $\begin{array}{l}\text { I had more difficulties than usual to } \\
\text { motivate myself. }\end{array}$ & $\begin{array}{r}15.0 \% \\
3\end{array}$ & $\begin{array}{r}15.0 \% \\
3\end{array}$ & $\begin{array}{r}10.0 \% \\
2\end{array}$ & $\begin{array}{r}25.0 \% \\
5\end{array}$ & $\begin{array}{r}35.0 \% \\
7\end{array}$ & 20 & 3.50 \\
\hline $\begin{array}{l}\text { I had more difficulties than usual to } \\
\text { concentrate on the project. }\end{array}$ & $\begin{array}{r}10.0 \% \\
2\end{array}$ & $\begin{array}{r}15.0 \% \\
3\end{array}$ & $\begin{array}{r}20.0 \% \\
4\end{array}$ & $\begin{array}{r}25.0 \% \\
5\end{array}$ & $\begin{array}{r}30.0 \% \\
6\end{array}$ & 20 & 3.50 \\
\hline $\begin{array}{l}\text { I had more difficulties than usual to } \\
\text { separate private and university } \\
\text { activities. }\end{array}$ & $\begin{array}{r}0.0 \% \\
0\end{array}$ & $\begin{array}{r}5.0 \% \\
1\end{array}$ & $\begin{array}{r}20.0 \% \\
4\end{array}$ & $\begin{array}{r}10.0 \% \\
2\end{array}$ & $\begin{array}{r}65.0 \% \\
13\end{array}$ & 20 & 4.35 \\
\hline I worked more than usual. & $\begin{array}{r}5.0 \% \\
1\end{array}$ & $\begin{array}{r}25.0 \% \\
5\end{array}$ & $\begin{array}{r}5.0 \% \\
1\end{array}$ & $\begin{array}{r}40.0 \% \\
8\end{array}$ & $\begin{array}{r}25.0 \% \\
5\end{array}$ & 20 & 3.55 \\
\hline $\begin{array}{l}\text { I missed being together with my } \\
\text { team members in "real life". }\end{array}$ & $\begin{array}{r}5.0 \% \\
1\end{array}$ & $\begin{array}{r}0.0 \% \\
0\end{array}$ & $\begin{array}{r}10.0 \% \\
2\end{array}$ & $\begin{array}{r}20.0 \% \\
4\end{array}$ & $\begin{array}{r}65.0 \% \\
13\end{array}$ & 20 & 4.40 \\
\hline
\end{tabular}

Reflecting on their experiences with remote development in their statements (both in the survey and the postmortems) - which include an implicit comparison with their experiences from previous game development projects - students came to different conclusions. While the majority of students emphasized the challenges that come with remote development in pandemic times, others did not perceive major challenges, partly because of prior experiences in developing remotely from previous projects in- and outside university. A few students even stress the advantages of remote development over local development.

With the following comprehensive collection of statements, we document the majority opinion that remote development during pandemic times was rather challenging - although some of our students reported that they could build on previous experiences from past development projects (which included various forms of remote works) and/or that they were able to overcome the perceived challenges. As already seen in the analysis of this survey's data, the reported challenges were mostly psychosocial. Many times, the perceived challenges imply and/or correlate with a lack of motivation:

Less and less direct contact with team members, no working together/in parallel and at location, less motivation, less opportunities for team building in the beginning, less 'fixed' times working on the project because of the missing on location work days. (SUK)

No motivation because no possibility of working at cgl, which has been essential in the past to make good games. Talking via technology is simply not good enough. Lack of communication leads to frustration. In the end it was doable, but no fun at all. (SUK)

We were slightly slower and it ws harder to track the progress of all team-members sometimes. Working side by side gives a better overview about the current state of the project, since sometimes it appears that a bad connection (or a team-member forgot the meeting) made it impossible to share daily progress. (SUK)

Previously we would meet 2-3 times a week in person. This sped up alot of difficult discussions and 
problems we faced during every development. Now we replaced these meetings with online sessions where we mostly use screenshare to show progress, discuss problems etc. Keeping motivation high was definitely much more difficult this time around. Feeling socially isolated did not motivate me to work more at all. (SUK)

While the project clearly showed us that working remotely is not necessarily bad, I think that working together closely face to face and spending time together like going to the cinema or getting dinner together is very important for mental health and team spirit and I personally would most likely not be able to work like this for a very long project. For me, game development is a very challenging interdisciplinary task and having a good atmosphere and a good state of mind is crucial not only for creativity but also for productivity and to endure tricky phases of a project. (G9/S3)

My other big takeaway is that (surprise surprise) communication is important, but this time regarding the COVID-19 pandemic. Working from home without the possibility of meeting up and discussing things in person, or simply working next to each other, was, in my opinion, disastrous. In previous projects, I heavily relied on this to get up to date on the state of the game, or debate gameplay decisions and plan future mechanics, but this time I felt very much on my own. Of course, there are a myriad of ways to stay in touch over the internet, but none of them come close to real life. I see now that meetings are crucial and hugely facilitate a smooth development phase. (G8/S1)

However, I could really feel the repetitive nature of being inside and essentially alternating between coding and playing video games or reading taking a toll on me mentally after a while. Without setting aside some days to rest and focus on physical training at home or just talking to my team members for fun, I feel like this project could have led to some mental burnout. (G6/S3)

Not being able to meet or to have a proper schedule really took a toll on my concentration and work ethic. By not being in a work placelike university $\mathrm{i}$ had a hard time actually getting into a work mindset, because connecting the leisure and relaxing focused atmosphere of my room with work is not something i'm used to doing. You know, work is at work, break is at home. (G6/S4)

Not but least, we all burned out at some point of the project. Using online tools may be a solution to work simultaneously and from being home, but it doesn't give any emotion from the other side of the screen. Staying in front of the screen for many hours obviously takes some toll into our physical and mental health. Sometimes it induces back pain or gets into a 'fight or flight' situation. [...] As being in a foreign country, thinking about home and family members' conditions, upcoming financial depression, adopting the new way of working etc. make it harder sometimes to keep concentrating on the project. Additionally, living in a small space, at some point it became hard to differentiate between the workspace and relaxation space. Without usual person to person contact with team members, sometimes it made me feel like a cyborg. On top of that, connection problems, the usual crashing of the game engine, learning to use new tools etc didn't make it easy. It took some initiative to keep the whole team safe from burning out and it was not a simple task. (G4/S1)

I don't know if it's the fact that it feels too impersonal but trying to communicate ideas in meetings proved to be one of the hardest things for me in this project. Not only that, but the fact that everything I'm doing had to be done on the computer, at my own home, kind of gave me the feeling like I couldn't escape from the project even when it wasn't even necessary for me to work on it. So yeah, it might be cool to work remotely when you have a separate room as an office, but not when you live in a small apartment where there's no escape. (G2/S2)

I work, eat and sleep in the same room, so it is sometimes difficult to detach from the project and clear one's mind. [The game] always seemed to be looming over me. A related but different problem was also how easy it was to get distracted. Home and its comforts do not always inspire a very productive work environment. (G2/S5)

In contrast to the above-documented statements of students who emphasized on the challenges, the following statements come from students who did not perceive major difficulties and stated that everything went smoothly:

In the majority of time working remotely worked way better than expected. (G1/S3)

From the start of the project, we updated each other almost daily on our tasks, what we were working on, and where our priorities were during each milestone. The communication between all of us went smoothly and whenever someone faced an issue, everyone was very forward coming and up to help. (G10/S1) 
In conclusion, I am very happy with the final result. Not only the game itself but also with the teamwork. We kept ourselves updated at all times through discord by sharing our progress and talking about possible improvements. For the presentations, we always made a call and worked together at the same time on the slides and the presentation texts which I then recorded and put over the slides. (G10/S3)

The remote teamwork went a lot better than anticipated. We held long meetings twice a day and used the same methods and tools as always, and surprisingly, it just worked. (G9/S3)

In regards to the team I couldn't have wished for better teammates. The organization worked perfectly over Trello and after a while we were so familiar with each other that members often took up supportive tasks such as looking for fitting audio, while the other was busy cutting the video for example by themselves. Sometimes we overscheduled and did a meeting that turned out to be a quick confirmation call that took maybe 12 minutes out of our day, but given the circumstances I believe we could have done worse and we all agreed that one meeting to many may be better than one to few. (G5/S2)

If somebody would ask me what type of game developer I am, I would answer, that I am the type that would meet their team every work day to develop together. Even on weekends, if possible. I liked meeting up. It's an easy way to communicate, as everyone is at the same spot. You can ask questions, show a quick sketch or ask for advice. With the pandemic running over us like the armies of Mordor over Helm's Deep, I felt really worried about the communication for our game project. In the past often happened, the lesser we met, the worse got our communication and productivity. But beside all my fears of us failing, it just didn't happen. The communication only over discord worked unbelievable well. For myself I can say, that especially because of this new situation out of my comfort zone, I felt even more ambitious to work well. (G5/S1)

A couple of students explained the absence of bigger difficulties with their previous experiences in remote development in- or outside university:

Working from home was another huge aspect of our project phase this year. However, to us, this was normality in our lives long before the Corona Pandemic. All of us are used to freelancing or working on semester projects remotely, therefore we were very comfortable with the situation in this regard. I think that's one of the main factors why our project phase went so smoothly since no one had to adjust to working from home. (G10/S1)

Working remotely went pretty well for us. I imagine that is because a lot of collaborative projects are largely remote to begin with, so this is not a huge adjustment. (G6/S2)

Besides the in-person meeting that we had in the previous semesters, everything was the same for me. I have been working remote in the previous semesters as well. (SUK)

I have experience working remotely on different projects and I've worked with my teammates in other projects before so I didn't have any problem working at home. (SUK)

While this was my first remotely done university project, I have already been working remotely on other things so that was not a deal breaker to me. (G1/S1)

Finally, a few students point to the advantages of working remotely:

We were more focused, as doing voice chat becomes over time really exhausting. Therefore, we tried to work more efficient. We also had less problems with people being not on time, as nobody could have trouble with local transportation. (SUK)

I think i worked way more focused and effective. (SUK)

I have written a lot rather than previous time. I was able to write design document in more detail. And think more. (SUK)

Refreshingly, I could work at my own pace, and own times. I prefer getting up early, and would prepare documents etc. before the meetings with others, something that would not have happened as routinely if we worked on site as usual. Workdays for me also got longer, as there was no clear distinction between work time and place, and leisure time. My Game Design Documentation also got a lot more detailed, self-explanatory and was updated more regularly. (SUK)

\subsubsection{Perceived Enjoyment}

Although some students have enjoyed remote development ("Honestly, working remotely was kind of fun and I 
wouldn't mind doing this again." - G7/S1), most of them favor developing games without physical distance. $52.64 \%$ (strongly) disagreed with the claim that working from home is more enjoyable than working from campus (CGL), a studio, or a co-working space (see Figure 6). A couple of students even detest remote development, as they explicitly told us in the survey or their postmortem. For these students, game development is an inherently social activity which requires physical presence. In their opinion, remote work "takes the fun out of game development" (SUK). However, qualitative data also reveal that in many cases, students' dislike of pure remote development does not correlate with a negative assessment of their final product.

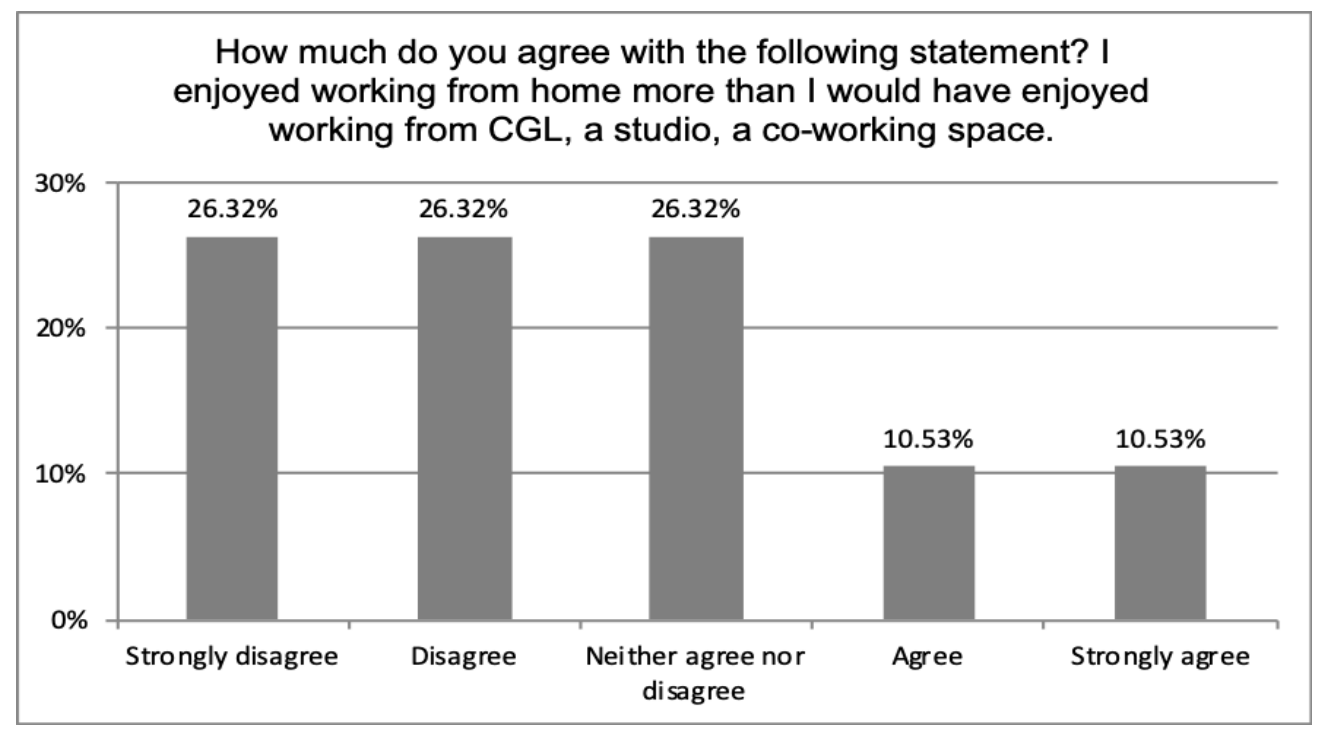

Figure 6. Perceived enjoyment of working from home (answered by 19, skipped by 3 )

Statements expressing an aversion to pure remote development were more prevalent and partly stronger in tone than those stating enjoyment. In a lot of cases, the aversion correlates with demotivation:

It is actively detrimental to the project, demotivates, and takes the fun out of game development by adding a layer of communication to every single decision or question. It is fine to work from home if there are regular meetings in person, but doing the entire project 'on your own' was not a good experience at all. (SUK)

Working Remotely: I do not like it. I actually kind of hate it. (G2/S2)

That said, for me the joy in game development comes largely from the social interactions around making games, and I want to return to working together in person as soon as possible. (G9/S3)

\subsection{Learning Processes and Outcomes}

According to our survey data, the majority of students (68.42\%) rated their personal improvements of knowledge and/or skills in the domain of online collaboration at 4 or 5 on a scale from 1 (low) to 5 (high), while a lower number of students (47.37\%) assessed their progress in online communication in this range. The perceived learnings in both of these domains - which are directly related to remote development - prevail over learnings in the domain of developing impact games $(42.1 \%)$, which is usually the main learning outcome addressed in the syllabus of the impact games project when it is not designed as a remote development learning experience (see Table 4). 
Table 4. How would you rate your personal improvements of knowledge and/or skills in the following domains? (answered by 19 , skipped by 3 )

\begin{tabular}{l|r|r|r|r|r|r|r} 
& LOW & (NO LABEL) & MODERATE & (NO LABEL) & HIGH & TOTAL & WEIGHTED AVERAGE \\
\hline Online communication & $10.5 \%$ & $15.8 \%$ & $26.3 \%$ & $36.8 \%$ & $10.5 \%$ & & \\
& 2 & 3 & 5 & 7 & 2 & 19 & 3.21 \\
\hline Online collaboration & $10.5 \%$ & $10.5 \%$ & $10.5 \%$ & $52.6 \%$ & $15.8 \%$ & & \\
& 2 & 2 & 2 & 10 & 3 & 19 & 3.53 \\
\hline Project management & $5.3 \%$ & $15.8 \%$ & $42.1 \%$ & $15.8 \%$ & $21.1 \%$ & & \\
\hline Developing impact games & 1 & 3 & 8 & 3 & 4 & 19 & 3.32 \\
\hline
\end{tabular}

An analysis of students' descriptions of their individual learnings about developing games remotely (based on their answers in the survey to the open question what they have learned in the project about developing games over distance) reveals three major areas of soft skill development:

- Organization: "time management - Saying no - set deadlines"; "the importance of documentation. having regular calls. managing the structure of our calls to make it more efficient."; "Meetings need an agenda or it gets our if Hand".

- Communication: "All in all, I had seen this project phase as a chance to improve my communication skills within a team in a remote working context and believe that I have succeeded in doing so"; "I would say I learned many things like [...] how to communicate very well [...] to clarify the tasks for team member to avoid any missing Understanding".

- Psychology - to cope with the psychosocial challenges of remote work (during a pandemic): "You have to learn to do more things independently and ask for constant feedback. You have to be able to seperate work and 'fun' when you work from home."; "It also teaches me how to cope up with different situations and going on forward - even in pandemic times."; "I have also learned how to keep my mental health safe in anxiety moments."; "be open to deal with problems like bad internet connection or sometimes not traceable progress, keep following up afterwards and don't get upset too fast - meeting up regularly is important to share progress and keep the teams motivation on track - force yourself to take care about the project and don't procrestinate when running into problems or have distracting things going on at home - care about youtr teammates, since not everybody is dealing the same with the current situation and the occuring problems and the stress of the project phase".

In addition to individual learning and social learning processes inside of the development teams, learning also took place beyond teams, inside the broader network of students which can be interpreted as a community of practice. A lot of students interacted many times with students from other groups on a professional level - by offering feedback and/or replying to feedback they received. A few postings on the online platform Spaces were mandated by the syllabus, but a lot of students went beyond the required number of postings. According to data from our survey, $31.58 \%$ interacted a "few times a month", $15.79 \%$ "once or twice a week", and 15.79 "several time a week" with members of other groups on a professional level (see Figure 7). These interactions occurred not only in Spaces - as stipulated by the syllabus - but also on Discord. 82.35\% of students who have been engaged in these kinds of conversations said that the interactions took place on Discord (see Figure 8). It becomes apparent that students' own communication preferences prevail over those prescribed by the institution. While we have not observed students' interactions on Discord, we have collected all open intergroup communication in Spaces. A look into the threads of this online platform alone discloses promising forms of peer-to-peer learning and mentorships relationships (which cannot be discussed in this article due to its scope and restrictions of space). 


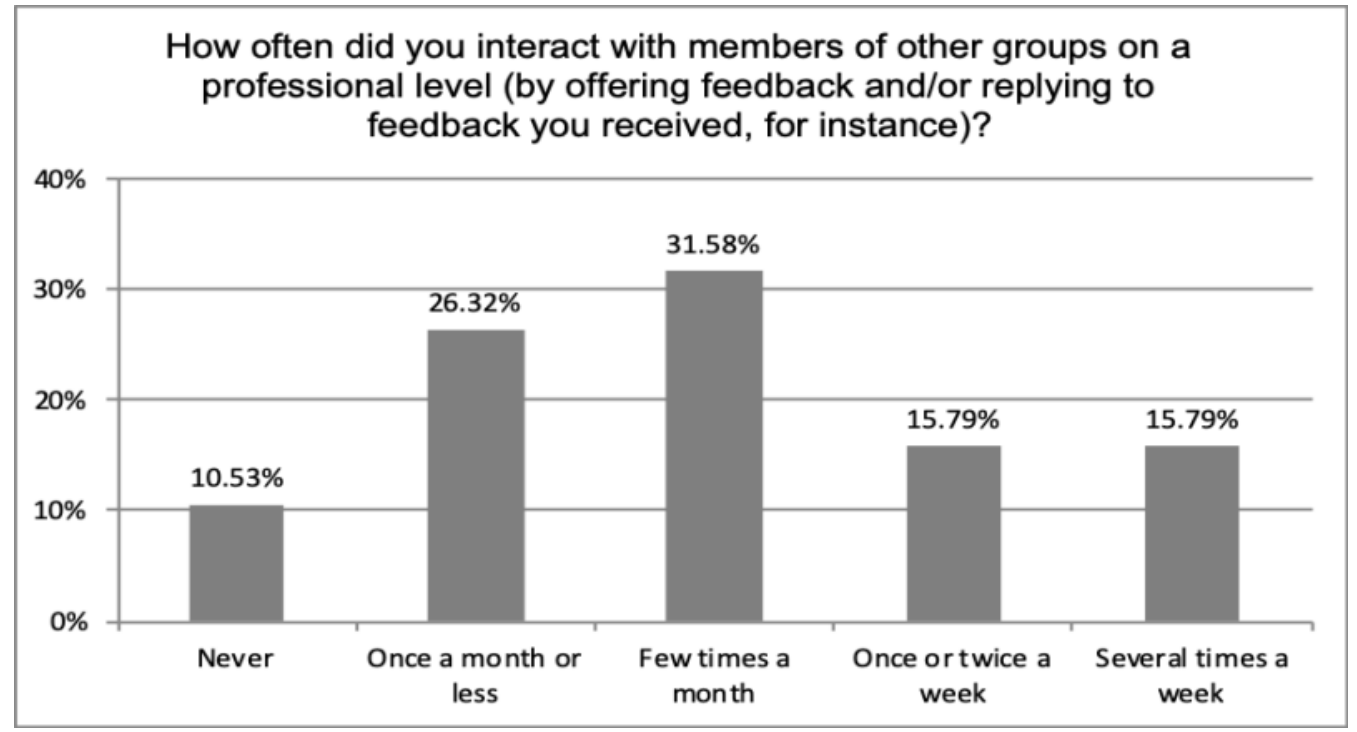

Figure 7. Interaction beyond groups (answered by 19, skipped by 3 )

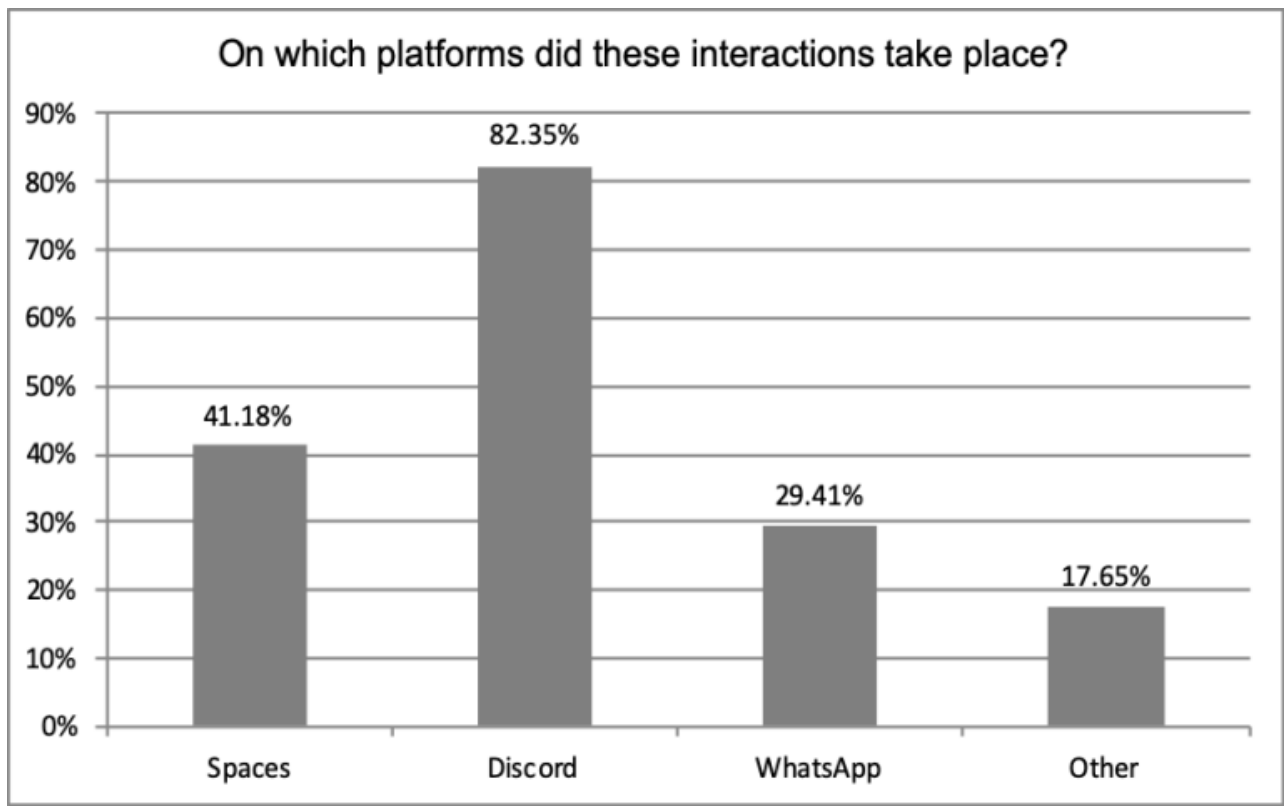

Figure 8. Platforms of inter-group interactions (answered by 17, skipped by 5 - multiple choices possible)

In the course of the project, the team of instructors tested two forms of project presentations: (1) live presentations / video conferences with everyone in a virtual classroom at the same time (synchronous mode - as applied in the final presentation via Zoom) (2) the upload of presentations on a platform that can be approached whenever students and lecturers like (asynchronous mode - as applied in the intermediate presentation via Spaces). The majority of students preferred the asynchronous format (63.16\%), whereas only a minority (10.53\%) favored the synchronous format (see Figure 9). This is insofar interesting as this preference stands in opposition to the current mainstream of distance learning in higher education which builds on the synchronous model, oftentimes based on Zoom meetings. 


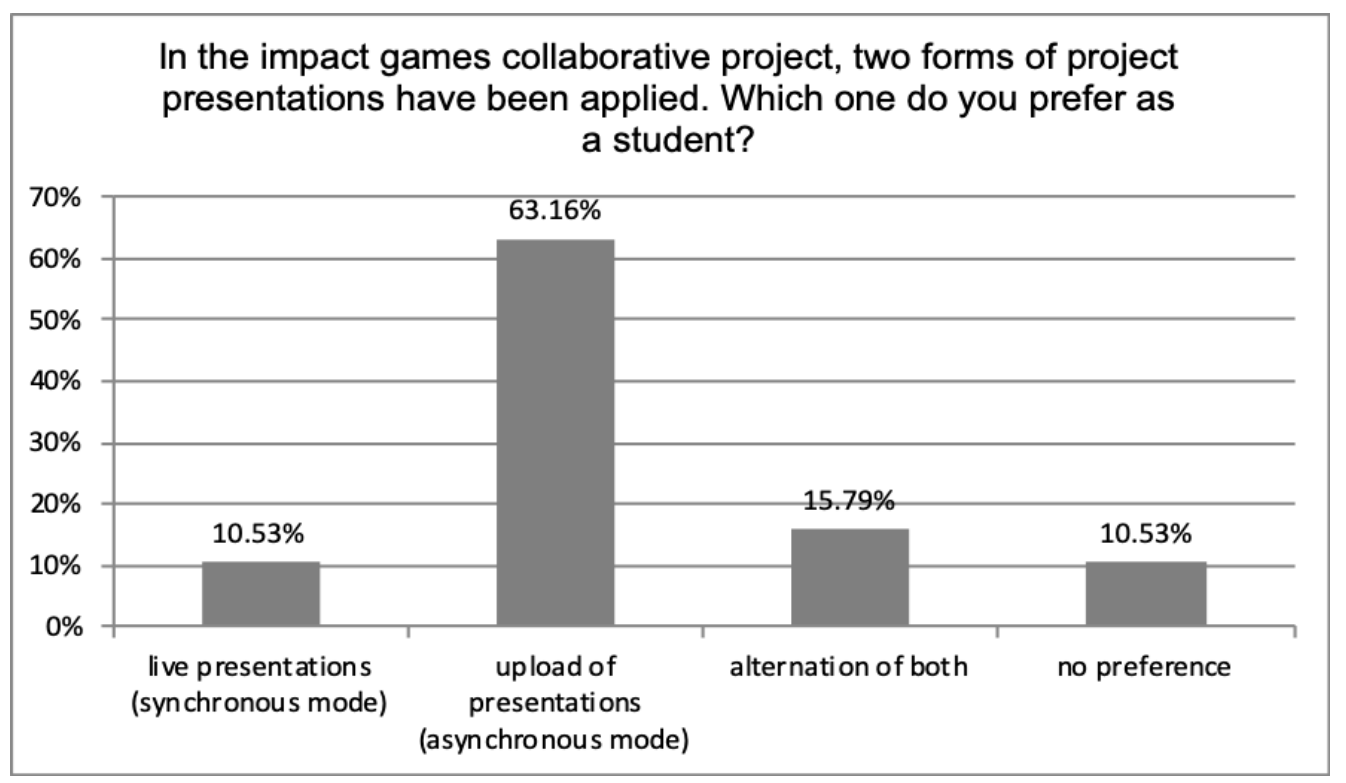

Figure 9. Preferred mode of classroom presentations (answered by 19, skipped by 3 )

Finally, 57.89\% of students believe that it is a good idea to offer a project-based module in remote development independent of the occurrence of a pandemic (see Figure 10):

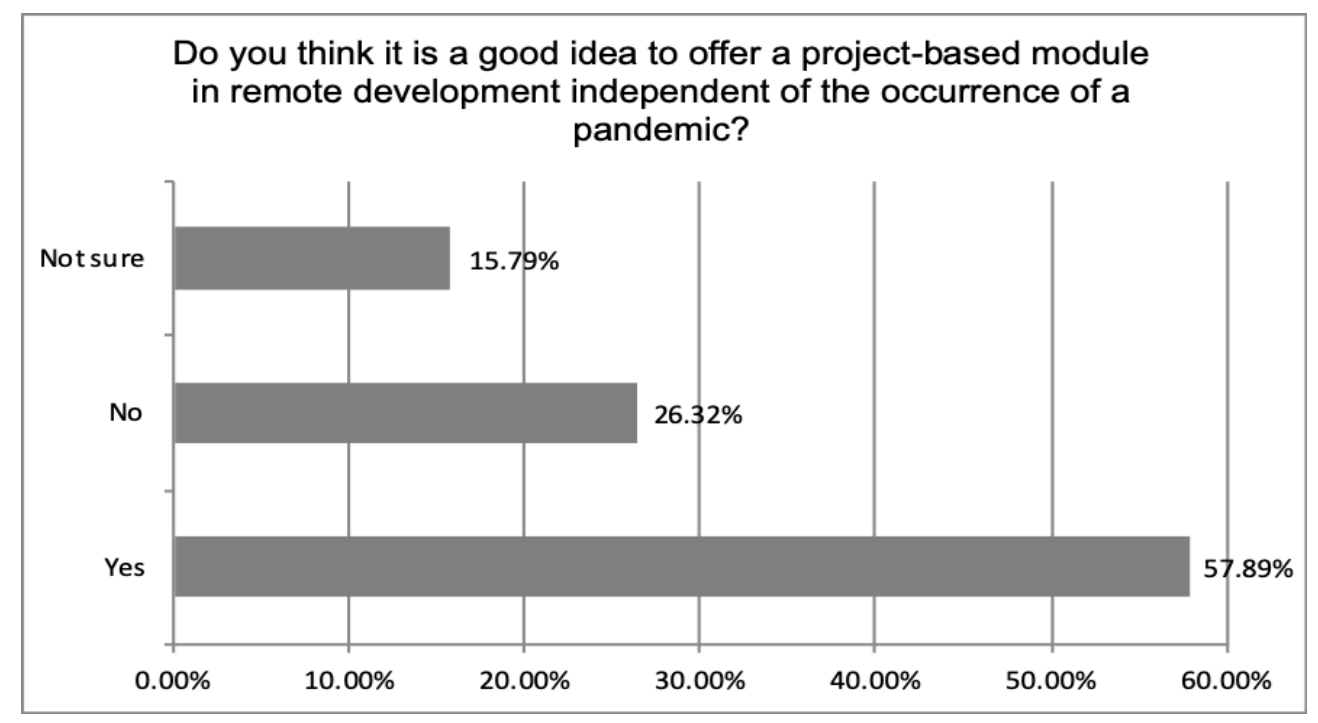

Figure 10. Importance of remote development module (answered by 19, skipped by 3 )

\section{Discussion}

The present paper illustrated results of a practice-based exploratory research which examined 30 third-year undergraduate students of game arts, game design, and game programming who remotely collaborated in groups of two to five persons over the course of half a semester in order to design digital impact games during Germany's logdown in spring 2020 caused by the coronavirus pandemic. Applying a mixed-method approach including quantitative and qualitative analyses of survey data $(n=22)$ and qualitative content analyses of students' postmortem documentations $(n=30)$, the study reconstructed the online practices, experiences, and learning processes of these students.

Although most students have not conducted a formal remote development course at university level previously, a lot of them were already familiar with remote work in general and a variety of relevant tools and practices in particular. Most of these experiences have been obtained from prior game projects in and outside of university in 
which they voluntarily applied a hybrid approach of developing games, combining team meetings and work on location with remote work respectively. Consequently, most students were able to smoothly adapt to the full remote work format and assessed the processes and outcomes of their work as successful from an academic and professional perspective. They were well aware that remote work requires additional attention and efforts when it comes to aspects such as time management, allocation of work, and mutual understanding. At the same time, they assume that these issues as well as technical problems can be overcome. However, a lot of students struggled with psychosocial challenges which may not only stem from the remote work setting as such, but also from the special situation during the pandemic and logdown (e.g. Marston et al., 2020; Mheidly et al., 2020). As a matter of fact, the present study cannot clearly differentiate between both (interconnected) reasons, i.e., cannot finally identify the causality of students' struggles. Fortunately, a lot of student groups were able to cope with the above-mentioned challenges by proactively maintaining/substituting parts of their work-related social life with the help of technology.

In its core, our study sheds light on the groups' collaborative practices, mediated by a variety of tools facilitating written and oral communication, real-time collaboration, exchange of data, etc. between the members of the communities of practice (Wenger, 2008; Wenger et al., 2009). For their practices, most groups heavily relied on the community platform Discord, which was already well-established among our students prior to the project as well as it is seen as superior to similar tools.

While some students did not like or even detested to work exclusively over physical distance, a small part of students enthusiastically embraced remote work. This difference in experience and opinion may most likely be explained by different personalities and/or social circumstances. Yet, further research is needed to explore this question.

All in all, the results of our study indicate a potential danger of remote work: that it may lead to unhappiness and psychological struggles for students/workers which might not only be to the detriment of their well-being, but also - in the long-run - their professional performance. However, it must be considered that our study examined a unique situation in which not only the working world, but also private life had to go "remote". Under normal circumstances, remote work may have been perceived as relieving to a far greater extent, as it would have allowed private real-world contacts, while still saving commuting time. Similarly, it may be hypothesized that the well-being of most students/workers as well as the processes and outcomes of their professional practices might benefit from hybrid forms of work more than from pure remote approaches - in both higher educational and vocational contexts. Further research is required to investigate these relationships.

Interestingly, in our study, some teams were able to manage their well-being internally by engaging themselves purposefully in recreational communication and activities on a regular basis. These activities included, in many cases, playing online games together, which is insofar obvious because games are their shared passion, but worth mentioning as recent research has shown a positive correlation between video game play and well-being (Johannes et al., 2020). It can be concluded that future courses on remote work should explicitly educate students in coping with the psychosocial challenges of working remotely over physical distance.

The study also explored students' self-perceived learnings. A higher number of students reported greater personal improvements of knowledge and/or skills in the domain of online collaboration than in the domain of online communication. This difference may be explained by evidence from our survey as well as students' postmortems which let us assume that they were already highly familiar with most applied tools of online communication, from private as well as professional experiences, which left a smaller margin for improvements. Strikingly, the perceived learnings in those domains related to remote work (online communication and online collaboration) prevail over perceived learnings in the domain of developing impact games, which is usually the main learning outcome addressed in the syllabus of the impact games project when it is not designed as remote development learning experience. In their qualitative statements, students described significant learnings in the area of soft skills, which are essential when it comes to remote work in particular, but also project work in general. Most of these self-reported soft skills can be categorized in the areas of (1) organization, (2) communication, (3) psychology - to cope with the psychosocial challenges of remote work (during a pandemic).

Finally, the results point to the importance of a wider network of learners - beyond the team level, encompassing all students of the class, who constitute a community of practice whose members are digitally connected via a variety of tools (Wenger, 2008; Wenger et al., 2009). A look into threads of the online platform Spaces alone discloses promising forms of peer-to-peer learning and mentorship relationships between students and mentoring instructors. Although we possess the mentioned data, we haven't investigated them in this article due to its scope and restrictions of space. We will analyze these data in a future study. 
Certainly, the present study - based on an exploratory mixed-method design - focusing on students' practices, experiences, and learnings in one course of a game development program in Germany, during the special situation of the early coronavirus pandemic in spring 2020, has its limitations. Among other things, it cannot be representative for all game development students across universities, let alone for students of other study programs, who presumably differ from game development students in several ways. Students from other, less project-oriented and less digital-focused programs, for instance, may bring a lower level of prior experiences with online communication and collaboration in interdisciplinary teams. Future studies should therefore broaden the perspective and investigate programs beyond games education.

As stated in the introduction, the coronavirus pandemic hit universities rather unprepared for distance education (Bozkurt et al., 2020), which is in particular true in the German case (Kerres, 2020) and - despite its digital focus - also true for the examined game development program. In addition, games education had also neglected the design of courses for remote work and distance development notwithstanding their prevalence in the gaming industry even prior to the pandemic. By offering insights into game development students' experiences, opinions, and particular needs, the results of this study can be used to inform the creation of accurately fitting well-designed curricula for remote game work and distance development that go beyond "emergency remote education" (Bozkurt et al., 2020). Since communication and collaboration skills are similarly relevant for other project-focused disciplines, such as design, digital media, and software engineering, the results of this study may be useful for these disciplines as well.

Lastly, it can be concluded that physical distance still matters (Olson \& Olson, 2000). Thus, the development of curricula focusing on remote work and distance development including interdisciplinary and intercultural communication and collaboration should be of paramount importance across disciplines. As such, these curricula must not only address professional practices, but also psychosocial challenges.

\section{Acknowledgments}

We would like to thank our students for offering us valuable insights into their work and thought processes, Alexandra Petrus for copyediting the manuscript, and Gundolf S. Freyermuth for providing constructive feedback on an earlier version of this paper.

\section{References}

Bozkurt, A., Jung, I., Xiao, J., Vladimirschi, V., Schuwer, R., Egorov, G., Lambert, S., Al-Freih, M., Pete, J., \& Olcott Jr, D. (2020). A global outlook to the interruption of education due to COVID-19 Pandemic: Navigating in a time of uncertainty and crisis. Asian Journal of Distance Education, 15(1), 1-126.

Czauderna, A. (2018). Academic Game Design Education: A Comparative Perspective. In S. Göbel, A. Garcia-Agundez, T. Tregel, M. Ma, J. Baalsrud Hauge, M. Oliveira, T. Marsh, \& P. Caserman (Eds.), Serious Games (Bd. 11243, S. 9-12). Springer International Publishing. https://doi.org/10.1007/978-3-030-02762-9_2

Damian, D. E., \& Zowghi, D. (2003). RE challenges in multi-site software development organisations. Requirements engineering, 8(3), 149-160. https://doi.org/10.1007/s00766-003-0173-1

Francis, B. (2020, April 24). How Blizzard, Ubisoft, and other studios went remote in the time of COVID-19. Gamasutra. Retrieved from https://www.gamasutra.com/view/news/361537/How_Blizzard_Ubisoft_and_ other_studios_went_remote_in_the_time_of_COVID19.php

Johannes, N., Vuorre, M., \& Przybylski, A. K. (2020). Video game play is positively correlated with well-being [Preprint]. PsyArXiv. https://doi.org/10.31234/osf.io/qrjza

Kerres, M. (2020). Against All Odds: Education in Germany Coping with Covid-19. Postdigital Science and Education, 2(3), 690-694. https://doi.org/10.1007/s42438-020-00130-7

Lave, J. (1996). Teaching, as learning, in practice. Mind, culture, and activity, 3(3), 149-164. https://doi.org/10.1207/s15327884mca0303_2

Lave, J., \& Wenger, E. (1991). Situated learning: Legitimate peripheral participation. Cambridge university press. https://doi.org/10.1017/CBO9780511815355

Marston, H. R., Ivan, L., Fernández-Ardèvol, M., Rosales Climent, A., Gómez-León, M., Blanche-T, D., ... Rohner, R. (2020). COVID-19: Technology, Social Connections, Loneliness, and Leisure Activities: An International Study Protocol. Frontiers in Sociology, 5, 574811. https://doi.org/10.3389/fsoc.2020.574811

Mayring, P. (2004). Qualitative content analysis. A companion to qualitative research, 1(2004), 159-176. 
Mheidly, N., Fares, M. Y., \& Fares, J. (2020). Coping with Stress and Burnout associated with Telecommunication and Online Learning. Frontiers in Public Health, 8, 672. https://doi.org/10.3389/fpubh.2020.574969

Olson, G. M., \& Olson, J. S. (2000). Distance matters. Human-computer interaction, 15(2-3), 139-178. https://doi.org/10.1207/S15327051HCI1523_4

Wenger, E. (2008). Communities of practice: Learning, meaning, and identity. Cambridge Univ. Press.

Wenger, E., White, N., \& Smith, J. D. (2009). Digital habitats: Stewarding technology for communities. Cpsquare.

\section{Endnotes}

Endnote 1. Spelling and grammatical errors in students' written statements from the survey and postmortems have not been corrected. In case of the statements from the postmortems, we added an anonymized identifier referring to the respective student/author after the statement in brackets which includes a group number as well as a student number (at group level, i.e., from 1 to 5). G6/S1, for instance, means group 6, student 1, in other words, student 1 from group 6 . In case of statements from the survey, our data do not allow to credit statements to a particular student. In this case, statements are ascribed to the label SUK which means student unknown.

\section{Copyrights}

Copyright for this article is retained by the author(s), with first publication rights granted to the journal.

This is an open-access article distributed under the terms and conditions of the Creative Commons Attribution license (http://creativecommons.org/licenses/by/4.0/). 